\title{
Promoting Pupils' Achievement Towards Effective Cloud Computing in Mathematics Education: A Case of Using Virtual Magic Board for Teaching Surface Area
}

\author{
Ukeagbu Merry Ngozi \\ Department of Curriculum Instruction, Alvan Ikoku University of Education, Owerri Imo State, Nigeria \\ ukegbumerryngozie@yahoo.com
}

Eugene Chukwuemeka Unamba*

Department of Primary Education Studies, Alvan Ikoku University of Education, Owerri Imo State, Nigeria

"Corresponding Author, unambaec@yahoo.com

\section{Article Info \\ Article History: \\ Received July $20^{\text {th }}, 2018$ \\ Revised October $28^{\text {th }}, 2018$ \\ Accepted November $06^{\text {th }}, 2018$}

Keywords:

Cloud computing, mathematics, virtual magic board manipulative, achievement, surface area

\begin{abstract}
The study investigated pupil's achievement using virtual magic board manipulative in surface area. The quasi-experimental research approach of the pre-test-post test non-equivalent control group design was adopted. Based on the objectives, two research questions and two hypotheses guided the study. The population comprises all primary six (6) pupils in all the private schools in Owerri Municipal Council of Imo state. A sample size of one hundred and sixty-four (164) pupils participated in the study using simple random sampling technique. The instrument used for data collection is researchers made Mathematics achievement test (MAT) that was validated by two expert's judges from mathematics education and measurement and evaluation departments. The reliability of the instrument was determined using the Pearson Product Moment correlation method which yielded a value of 0.83 . The data generated were analyzed using mean, standard deviation, t-test, and ANCOVA. The hypotheses were tested at 0.05 level of significance. The results show that virtual magic board enhances primary school pupil's achievement in a surface area and the enhancement does not significantly depend on gender. Based on the findings it is recommended that workshops and seminars should be organized for mathematics teachers on the virtual magic board.
\end{abstract}

Copyright $(2019$ by the authors; licensee Department of Mathematics Education, University of Singaperbangsa Karawang. All rights reserved.

This is an open access article distributed under the terms of the CC BY-SA license. (http://creativecommons.org/licenses/by-sa/4.0)

\section{INTRODUCTION}

Mathematics remains the most serviceable subject to all disciplines and fields of human work and it has become an indispensable tool in the study of humanities, science, and technology which is recognized in many areas of human activities. Every individual needs some measure of mathematics for his or her day to day activities. Usefulness of mathematics in human activities cannot be underestimated because it is the precursor of scientific discourse and invention of which any nation that overlooks the study of mathematics and does not take interest in it would remain underdeveloped. Stressing the usefulness of mathematics, Pollak (1986) believed that the most fundamental reason why we place so much emphasis on mathematics is that mathematics is integral to everything 
about life. He added that every occupation which students may choose to pursue and much of their everyday lives are full of opportunities that need the application of mathematics.

Adegboye \& Adegboye (2003) observed its usefulness in other areas of study as well as in humanities such as arts, social science, religious mysticism, commerce, and war. This observation points to the fact that mathematics is not only universally useful and utilitarian in nature; it is also regarded as the key to the solution of human problems (Iyekepolor, 2007). The Federal Government of Nigeria has for long been aware of the pivotal position of mathematics to individual fulfillment and national developmental goals with particular reference to scientific and technological emancipation and breakthrough. This understanding has consequently led educational policymakers to position mathematics as a compulsory and of the core subjects in primary and secondary levels of education (FRN, 2004). It is also a requirement for pupils to proceed from upper basic to senior secondary level as well as for almost all courses in the tertiary level. Despite the high position offered to mathematics in Nigerian education system, it is highly dishearten that approaches and strategies used for teaching and learning of the subject at both primary and secondary level are not probably being put to use effectively in a manner that could promote learner's activity and provide learner's guided practice enabling them to retain concepts taught and solve problems.

Generally, students fear, hate and dislike mathematics because they see it as the abstract subject. This has resulted in their lack of interest, anxiety and low retention rate which leads to poor performance in mathematics examinations, both internally and externally (Obodo, 2010). Reporting to the National Council on Education (NCE) on student's performance in the Unity schools examinations expressed worries over the low achievement due to poor retention rate and lack of interest in mathematics by Nigerian candidates (Ministry of Education, 2014). Kurumeh (2007) maintained that the inappropriate and inadequate methods used by mathematics teachers are instrumental to learners inability to understand the basic mathematical facts that resulted to learning by role memorization, low performance and lack of interest in mathematics. Resourcefulness in mathematics teaching demands that the mathematics teachers should focus attention on methods of teaching, innovates technology that stimulates learner's zeal, interest, and higher retention rate, taking into cognizance of individual difference of learners. This then suggests that mathematics educators should be able to develop new teaching techniques. Mathematics is distributed into many branches which include trigonometry, number, and numeration, algebra, geometry, surface area of shapes.

Surface area of a branch of mathematics that deals with solid shapes. It involves putting real-life problem into problem-solving. The most important outcomes in the study of surface area include the ability to think logically, use principles to see relationship, and to analyze and to organize (Orji \& Anaduake, 2010). Surface area is the quaintly that express the extent of two-dimensional figure. Eskay \& Onu (2012) stated that surface area of objects as one of the major branches that mathematics concern itself with the study of the structures. According to Koirala (2005) mathematics teachers, mathematics teacher educators and mathematician consider surface area to be one of the most important areas in school mathematics. Brain (2010) stated that surface area which is a major branch of mathematics is important for the cognitive, critical and analytical skills of the pupils that enable them to solve real-life problems logically. Ministry of education (2010) showed that surface area as a branch of geometry is one area pupils found it very different to handle. They cannot understand how to calculate surface area of 2D and 3D shapes. The inability of pupils to engage in the learning process tends to dispose the pupils to constant role learning. Gladima (2002) noted that poor quality instructional technique causes poor 
achievement among primary school pupils in mathematics. This then suggests new teaching technique like use of cloud computing.

Cloud computing is a technology that uses the internet and central remote servers to maintain data and application (Ahmed, 2013). Cloud computing allows consumers and business managers to use applications without installation and access their personal files. Cloud computing is the use of computing resources (hardware and software) that are delivered as a server over a network (typically the internet). It can be grouped into the following categories. Infrastructure as a service (Iaas), software as a service (Saas) and platform as a service (Paas). Hosseinis et al (2014) outlined the benefits of cloud computing as follows (i) Access to applications from anywhere (ii) support for teaching and learning, software for pay per use, 24hours access to infrastructure and content, protection of students to new technologies and increasing functional capabilities. The use of cloud computing in teaching and learning mathematics concepts, will shifts the process from teacher-centered approach to students activity centered as opined by Mari (2002) that teaching mathematics with cloud computing technology is a variable strategy that can easily be manipulated by teachers to increase student functional capabilities as well as enhance sex-related differences in science and mathematics performance. The call for use of cloud computing in Nigerian education supports the use of cloud computing manipulative known as the virtual magic board in teaching and learning of mathematics.

Magic Board is a well-known cloud virtual manipulative developed by Yuan (2005). It consists of three important components namely magic board software, a problem center, and an instructional material center. Magic board can be accessed at http://magicboardcycu.edu. It can be accessed for free. Users only need to drag and copy to compile their own instructional materials, and subsequently, upload them to share with other friend users. When a user registers as a member of magic board, he or she can use all the components. The first component of magic board software (MBS) can be accessed from the upper right corner of the website home page by clicking the "Try English Version" button. MBS had the frequently used elementary mathematics manipulative digitalized and computerized in the toolbar which allows users instant access during instruction. Users can drag these objects to the display area and a right-click allows access to property variation and operations.

Problem Centre (PC) users can log into the Magic Board platform to use resources from the PC. They can search for uploaded problems according to the level of their pupils/students and mathematical content. The teaching materials can be saved and uploaded as users click on saved/upload bottom on the Function Area.

Instructional Material Centre (IMC) by clicking an organized instructional material, users can browse through problems and chose suitable resources materials to personalize the instructional materials. Once users have centered organize instructional materials, materials searched and checked the problems, the right-hand column numbers of the problems according to their picking order. The virtual manipulatives are used to builds concrete representation of abstract in surface area. However, recent assessments of mathematical achievement indicate that the use of virtual manipulatives in teaching and learning of mathematics holds the promise that it arouse and sustain learns interest in an activity and ensures active participation of learners and enhances students learning. Ado (2012) making declaration about manipulative stated that it makes students think and discover mathematics ideas and facilities creative thinking. It motivates the students and provides a mean of making independent Investigation by the student on the concepts being taught in class and also enhances retention of knowledge. 
Empirical studies related to the virtual manipulative for mathematics learning are still relatively new. Ainsa (1999) observed no significant difference between virtual manipulative in color matching number matching, shape identification, counting ability or addition/subtraction in another study, $3^{\text {rd }}$-grade students mastered classification and logical thinking equally using virtual manipulative and physical manipulative (Clements, Nastasi, \& Swaminathan 1993). Steen, Broots \& Lyon (2006) found that virtual manipulative can be effective as physical manipulative in learning geometry-related concepts among $1^{\text {st }}$ grade students. Yuan, Lee \& Wang (2010) observed no significant difference in the learning performance of students using virtual manipulative and those using physical manipulative when dealing with polyamines. However, new ideas using new symbols to record the results and considering the influences of symmetry and rotation on the figures occurred in the virtual manipulative. Suh \& Moyer (2007) examined the effects of developing student's representational fluency using virtual manipulative and physical manipulative. The results showed that although the different manipulative models had different features, both the physical and virtual environments were effective in supporting students' learning and encouraging relational thinking and algebraic reasoning.

However, Chang et al (2013) adopted a non-equivalent quasi-experimental design and recruited participants from two classes of $3^{\text {rd }}$ grade students in an elementary school in Taiwan. The results demonstrated the effectiveness of virtual manipulative over that of physical manipulative on three subscales of immediate learning performance and all four subscales of retention performance. Renimer \& Moyer (2005) also investigated the impact of virtual manipulatives on the instruction of equivalent fractions and the comparison of fraction size. Their results indicated that virtual manipulatives can enhance the learning of fractions compared to physical manipulative. Moreover, $60 \%$ of the students developed positive attitude toward the use of virtual manipulative. Most students appreciated the immediate feedback of this approach, which tends to be more convenient and efficient than using physical manipulative.

Moyer, Niezgoda, \& Stanley (2005) discussed virtual manipulative as a unique how two elementary school teachers conducted action research projects in their classroom using this technology. During these projects, a kindergarten teacher and a $2^{\text {nd }}$ grade teacher taught a series of lessons and documented children's used of two virtual manipulative. In these classrooms, teachers used the concrete manipulative prior to using manipulative. The findings demonstrated that children using virtual manipulative were more creative in the formation of geometric patterns. These studies showed that virtual manipulative help students to perform equally or better than physical manipulative. However, most of the participants of these studies were elementary school students and most of these studies were based on independent projects. These were supplementary courses, not included in the regular instruction. Moreover, little is known for the interaction between prior knowledge and manipulative on learning effects. Therefore, this study uses type of manipulative and level of prior knowledge as independent variables to examine junior high school students' learning performance of plane geometry, using curriculum based on van Hiele's five-stage learning theory. In addition the course was implemented within the schedule of regular instruction.

\section{Statement of the Problem}

Most primary schools in Nigeria view mathematics as problematic and abstract probably because students have great difficulty in understanding, assimilating and retention of the mathematics taught to them in surface area especially in the classroom. 
Report from the Ministry of Education (2010) revealed some of the problems encounter by learners in surface area as their inability to gain adequate experience In visualizing geometric figures, inability to differentiate between plane and solid figures, not familiar with the properties on which the formula are based which are associated with ways it is being taught in the classroom. Kurumeh (2007) maintained that the mathematics taught in schools is foreign, Eurocentric in origin and build on western cultural background making students to learn by rote of memorization in which the attendant result is consistent mass failure of students. This has given rise to pupils achieving poorly in mathematics at both internal and external examination especially in calculating surface area noted by Ministry of Education (2010). Therefore, the study looked at how to promote pupils achievement in surface area using virtual magic manipulative.

\section{Purpose of the Study}

The main purpose of the study is to investigate how to promote pupils achievement in surface area using virtual magic board. Specifically, the study will determine whether.

1. Pupils taught surface area of shapes using virtual magic board manipulative will have better achievement than those taught conventionally

2. Male and female pupils will differ in their achievements in surface area of shapes after being taught using virtual magic board manipulative.

\section{Research Questions}

The following research questions guided the study:

1. What is the difference between the mean achievement scores of pupils taught surface area of shapes using virtual magic manipulative and those taught conventionally using talk and chalk.

2. What is the difference between the mean achievement scores of male and female pupils taught surface area of shapes using virtual magic manipulative?

\section{Research Hypotheses}

These hypotheses guided the study at 0.05 level of significant:

1. There is no significant difference between the mean achievement scores of pupils taught surface area using magic board manipulative and those taught conventionally using talk and chalk.

2. There is no significant difference between the post-test mean achievement scores of male and female students taught using magic board manipulative.

\section{METHOD}

The design of the study was quasi-experimental research type adopting pre-test, post-test, non-equivalent control group design. This was adopted because it was not possible to have a complete randomization of the subjects involved in the study. The population of the study consists of all private primary six (6) pupils in Owerri Municipal Council Area of Imo State. The sample of the study, consist of 164 pupils drawn from two 
randomly selected private primary schools from the area. The sample consists of 72 male and 92 female students. In each of the schools selected, two intact classes were randomly assigned to experimental and control groups. The experimental group had 77 students made up of 32 male and 45 female pupils while the control group had 87 pupils made up of 40 male and 47 female pupils. The instrument used for data collection was a surface area achievement test (AAT). It was a 15-item objective test question constructed by the researcher with special attention on surfaces area on shapes. The construction of the instrument was however guided by a table specification. The face and content validity of the instrument was determined by two experts in mathematics education and one expert in measurement and evaluation department. Their inputs were given attention in restructuring their instrument. The reliability of the instrument was determined by administering it to a group of students outside the study group who had the same characteristics with the study group. The instrument was re-administered on them after two weeks interval. The scores of the tests were correlated using Pearson product moment correlation coefficient. This gave a collection coefficient ( $\mathrm{r}$ ) of 0.83 which was acceptable for the study.

In administering the instrument, the control and experimental groups were pretested to ensure equity in their cognitive background. After that, the experimental groups were taught surface area of shapes by trained research assistants who were teachers in the selected schools. The pupils were given opportunity to interact with the virtual magic board manipulative in the process of learning the concept. They used the magic board to resolve problems in surface areas of shapes They interacted with each other in the process of learning while the teacher guided them in difficult situations while the control groups were taught the same topic with the same lesson plan through, the conventional "talk-andchalk" method by their regular mathematics teachers. The process lasted for three weeks after which a post-test was administered on both groups. The post-test instrument was a rearranged version of the pretest. The data collected were analyzed using mean to answer the research questions while the hypotheses were analyzed using analysis of covariance (ANCOVA) tested at 0.05 level of significant.

\section{RESULTS AND DISCUSSION}

Research Question 1: What is the difference between the mean achievement scores of pupils taught surface area using magic board manipulative and those taught conventionally?

Table 1. Summary of pupils means achievement scores

\begin{tabular}{lllllll}
\hline Group & N & Test & Mean & SD & Mean Gain & Dff in Mean Gain \\
\hline Experimental & 77 & Pre test & 29.22 & 8.04 & & \\
& 77 & Post test & 52.30 & 9.39 & 23.08 & \\
Control & 87 & Pre test & 30.10 & 8.68 & & 22.86 \\
& 87 & Post test & 30.32 & 8.41 & 0.22 & \\
\hline
\end{tabular}

Table 1 show that, the experimental group had a mean achievement gain of 23.08 while the control group had 0.22 . This gave a difference in mean achievement gain of 22.86 in favour of the experimental group.

Research Question 2: What is the difference between the post test mean achievement scores of male and female pupils taught surface using virtual magic board manipulative? 
Table 2. Summary of Post test mean achievement scores of male and female pupils.

\begin{tabular}{lllll}
\hline Sex & N & Mean & SD & Diff in Mean \\
\hline Male & 32 & 52.41 & 10.31 & \\
Female & 45 & 52.22 & 8.80 & 0.19 \\
\hline
\end{tabular}

Table 2 show that a difference in post-test mean achievement scores of 0.19 exists between the male and female students. This minor difference is in favour of the male student in the group.

Ho$_{1}$ : There is no significant difference the mean achievement scores of JSS III students taught algebra using algebra tiles and those taught conventionally.

Table 3. ANCOVA analysis of students in experimental and control groups

\begin{tabular}{llllll}
\hline Source & $\begin{array}{l}\text { Type III sum } \\
\text { of squares }\end{array}$ & Df & $\begin{array}{l}\text { Mean } \\
\text { square }\end{array}$ & F & Sig \\
\hline Corrected model & 19978.701 & 4 & 4994.675 & 63.324 & .000 \\
Intercept & 18642.430 & 1 & 18642.430 & 336.355 & .000 \\
Covariate & 1.949 & 1 & 1.949 & .025 & .875 \\
Method & 18682.761 & 1 & 18682.761 & 236.866 & .000 \\
Sex & $\mathbf{1 2 5 . 5 8 9}$ & $\mathbf{1}$ & $\mathbf{1 2 5 . 5 8 9}$ & $\mathbf{1 . 5 9 2}$ & $\mathbf{. 2 0 9}$ \\
Method sex & $\mathbf{1 0 4 . 0 0 2}$ & $\mathbf{1}$ & $\mathbf{1 0 4 . 0 0 2}$ & $\mathbf{1 . 3 1 9}$ & $\mathbf{. 2 5 3}$ \\
Error & 1254.073 & 159 & 78.875 & & \\
Total & 303387.000 & 164 & & & \\
Corrected total & 32519.774 & 163 & & & \\
\hline
\end{tabular}

Table 2 shows that at the method row, f-calculated value (236.866) is greater than the critical value (3.84), also $p$-value (0.000) is less than 0.05 ( $p>0.05)$. Based on the result, the null hypothesis is rejected and the alternative accepted at 0.05 level of significance. This implies that a significant difference exists between the mean achievement scores of pupils taught surface area using virtual magic board manipulative and those taught conventionally.

$\mathrm{Ho}_{2}$ : There is no significant difference between the mean achievement scores of male and female pupils taught surface area using virtual magic board manipulative.

The sex row on table 3 shows that, f-calculated value (1.592) is less than the critical value (3.84), also p-value (.209) is greater than 0.05 ( $p>0.05)$. Based on the result, the null hypothesis is upheld at 0.05 level of significance.

\section{Discussion}

The findings of this study showed that, virtual magic board manipulative is effective in promoting pupils achievement in surface area. This was demonstrated through the high mean achievement gain of pupils in the experimental group as against those in the control group. Also the ANCOVA analysis showed that, a significant difference exists between the mean achievement scores of those taught using virtual magic board manipulative and those taught conventionally. This is suspected to be as a result of their interaction with the magic board manipulative during the learning process, also the strategy did not permit competition among the students. This result is in line with the findings of Steen, Broots, \& Lyon (2006) who found that virtual manipulative can be effective in learning geometryrelated concepts among $1^{\text {st }}$ grade students. 
The study also showed that, the female students improved on their mean achievement scores like their male counterparts taught using magic board manipulative as a minor gap existed between them. The ANCOVA analysis also showed so significant difference between them. This result is in tandem with the work of Larbi \& Okyere (2014) who noted that when girls and boys are instructed through extensive use of manipulative, girls benefit most, which enable them to perform at almost equal level as their male counterparts. This is as a result of non-discriminative nature of the strategy employed in teaching the concept.

\section{CONCLUSION}

The result showed that virtual magic board manipulative promoted primary pupils achievement in surface area irrespective of their gender. In this time when there is urgent need for a sound and improved quality of education to enhance national development, it has become pertinent to promote cloud computing in our education system such as the use of virtual manipulative in teaching mathematics. When students' achievement in mathematics is improved the quality of education and national development will be pointing in the right direction.

\section{Recommendation}

Based on the result of the study the following recommendations are made:

1. Workshops and seminars should be organized for mathematics teachers to enhance their knowledge on new wave of virtual instructional manipulative for teaching mathematics.

2. Mathematics teachers should use virtual manipulative environments in teaching and learning of geometry concepts in primary schools.

3. School administrators should encourage mathematics teachers through provision of cloud computing software for teaching and learning mathematics.

4. Computer Mathematics laboratories should be established in primary schools where mathematics teachers and pupils can interact with cloud computing

\section{REFERENCES}

Adegboye, AO., \& Adegboye, O.A (Jnr) (2003). The Use of Mathematics in Solving Mathematical Problems. Abacus. Journal of the Mathematics Association of Nigeria (MAN), 28(1), 67-77.

Ado, M.S. (2012). Effect of teaching arts on the mathematics achievement of juror secondary school (JSS0 students in Zara local Government Area of Kaduna Stat. Journal of science Technology and Education 1(1), 6-10.

Ainsa, T. (1999). Success of using Technology and manipulations to introduction numerical problems solving skills in monolingual/bilingual early childhood classroom. Journal of Computers in Mathematics and Science Teaching 18, 361369.

Ahmed, U.J.B. (2013). E-learning using could computing International. Journal of Science and Modem Engineering (IJISME) 1(2), 9-13. 
Brain, J. (2010). Studying surface area retrieved on $8^{\text {th }}$ March 2015 from http://www.articlesable.com/.

Chang, W.L Yuan, Y. Lee C.Y, Clen M.H., \& Huang W.G. (2013). Exploring the impact of using Magic Board as a teaching and in their grader learning of area concepts. Education Technology and Society 16(2), 163-173.

Clements, D.H, Nastasi, B.K., \& Swaminathan, S. (1993). Young children and computers: crossroads and directors from research. Young children.

Eskay, M., \& Onu.V. (2012). Effect of self-instruction strategy on the achievement in surface are of student with learning difficulty in mathematics us-china education review, $A(12)$, 1006-1021.

Federal Republic of Nigeria. (FRN, 2004). National Policy on Education. Yaba Lagos, NERDC Press.

Gladima, (2002). The relative effects of heuristic problems solving instruction on secondary school students performance on surface area. Journal of the mathematical association of Nigeria 27(1), 51-65.

Hosseinis, Gheysari, E, Mohseni, S., \& Farslud, S. (2014). Application of cloud computing Technology in improving education sets. Chemical and process engineering 36(2), 454-463.

Iyekepolor, S.A.O (2007). Cooperative Strategies for Combating Poor Performance in Mathematics. Makurdi; Onimsi Solid Press.

Koirala, H.P. (2005). Effect of Mathematics on the algebraic knowledge and skills of low performing high school students. Proceedings of the $29^{\text {th }}$ contrivance of the international group for the Psychology of Mathematics Education.

Kurumeh, M.S. (2007). Effects of Ethnomathematics Approach on Students' Interest in Geometry and Menstruation Abacus. Journal of the Mathematical Association of Nigeria, $(M A N), 32(1), 103-112$.

Larbi, E., \& Okyere, M. (2014). Algebra tiles manipulative and gender differences in learning and achievement in mathematics: A case of Sunyani West Municipality. Journal of Education and Practice, 5(38), 1-7.

Mari, J.S. (2002). Gender Related Differences in Acquisition of Formal Reasoning Schematic: Pedagogic Implication of Teaching Chemistry using Process-Based Approach. Journal of the Science Teachers Association of Nigeria 37(1 \& 2), 7680.

Ministry of Education (2010). Chief Examiner Report Imo.

Moyer, P.S, Niezgoda, D., \& Stanley, J. (2005). Young Children's Use of Virtual Manipulates and other forms of mathematics representation in N.J. Masalasla \& P.C. Elluiott (Eds). Technology-supported Mathematics Learning Environments.

Obodo, G.C. (2004). Principles and Practice of Mathematics Education in Nigeria. Enugu: Floxtone Press.

Orji, A.B.C., \& Anaduake, U. (2010). Effect of Webbing Instruction Strategy on Student's Achievement in Surface Area World Problems. Journal of Research in National Development, 8(2).

Pollak, H.O. (1986). The Effects of Technology on the Mathematics Curriulum. In Marjorie Carss (ed). Proceedings of the Fifth International Congress on Mathematical Education. Boston, Birkhauser, Inc.

Renimer, K., \& Moyer P.S. (2005). Thrived Grades Learn about Factors using Virtual Manipulators. A Classroom Study. Journal of Computers in Mathematics and Science Teaching, 24(10), 15-25. 
Steen, K, Broots, D., \& Lyon, T. (2006). The Impact of Virtual Manipulations on First Geometry Instructing and Learning. International. Journal of Computers in Mathematics and Science Teaching, 25, 373-391.

Suh, J., \& Moyer, P.S. (2007) Deterring Students' Representational Fluency using virtual and Physical Algebra Balances. Journal of Computer in Mathematics and Science Teaching, 26(2), 155.

Yuan, Y (2005). Design of Virtual Manipulates for Mathematical Explorations Using Flash Action Script Proceedings of the $10^{\text {th }}$ Asia Technology Conference in mathematics.

Yuan, Y., Lee, C.Y., \& Wang, C.H. (2010). A Comparison Study of Polyominopes Exploratory in a Physical and Virtual Manipulation Environment. Journal of Computer Assisted Learning, 26(4), 307-316.

\title{
Meningkatkan Hasil Belajar Siswa Menggunakan Cloud Computing dalam Pendidikan Matematika: Studi Kasus Penggunaan Virtual Magic Board Untuk Pengajaran Luas Permukaan
}

\author{
Ukeagbu Merry Ngozi \\ Program Studi Kurikulum dan Pembelajaran, Universitas Pendidikan Alvan Ikoku, Owerri Imo State, \\ Nigeria,ukegbumerryngozie@yahoo.com

\section{Eugene Chukwuemeka Unamba*} \\ Program Studi Pendidikan Dasar, Universitas Pendidikan Alvan Ikoku, Owerri Imo State, Nigeria \\ *Penulis Korespondensi,unambaec@yahoo.com
}

\begin{abstract}
ABSTRAK
Penelitian ini menelaah tentang pencapaian hasil belajar siswa menggunakan manipulasi virtual magic board pada luas permukaan. Pendekatan penelitian menggunakan kuasi eksperimen dengan mengadopsi desain pre-test post-test kelompok kontrol yang tidak setara. Berdasarkan tujuan, dua pertanyaan penelitian dan dua hipotesis memandu penelitian. Populasi terdiri dari enam siswa utama (6) di semua sekolah swasta di Owerri Municipal Council of Imo. Ukuran sampel dari seratus enam puluh empat (164) siswa berpartisipasi dalam penelitian menggunakan teknik simple random sampling. Instrumen yang digunakan untuk pengumpulan data adalah tes prestasi Matematika (MAT) yang dibuat oleh peneliti yang divalidasi oleh dua ahli dari departemen pendidikan dan pengukuran dan evaluasi matematika. Reliabilitas instrumen ditentukan dengan menggunakan metode korelasi product moment Pearson yang menghasilkan nilai 0,83. Data yang dihasilkan dianalisis menggunakan rata-rata, standar deviasi, t-test dan ANCOVA. Hipotesis diuji pada tingkat signifikansi 0,05. Hasil menunjukkan bahwa virtual magic board meningkatkan hasil belajar siswa sekolah dasar pada pokok bahasan luas permukaan dan peningkatannya tidak secara signifikan bergantung pada jenis kelamin. Berdasarkan temuan tersebut, direkomendasikan bahwa lokakarya dan seminar harus diatur untuk guru matematika pada penggunaan virtual magic board.
\end{abstract}

Kata kunci: Cloud computing, matematika, virtual magic board, hasil belajar, luas permukaan

Diterima 20 Juli 2018

Direvisi 28 Oktober 2018

Disetujui 06 November 2018 